Research Article

\title{
Factors Influencing Sleeve Grouting Quality for Prefabricated Building: An Interpretive Structural Modeling Approach
}

\author{
Yingbo Ji, ${ }^{1}$ Zihao Zhao, ${ }^{1}$ Fuyi Yao $\mathbb{D}^{2}{ }^{2}$ Hong Xian $\mathrm{Li},{ }^{3}$ Yanyao Li, ${ }^{1}$ and Xiaoyun $\mathrm{Du}^{2}$ \\ ${ }^{1}$ School of Civil Engineering, North China University of Technology, Beijing 100144, China \\ ${ }^{2}$ School of Management Science and Real Estate, Chongqing University, Chongqing 400044, China \\ ${ }^{3}$ School of Architecture \& Built Environment, Deakin University, Geelong Waterfront Campus, Locked Bag 20001, Geelong, \\ VIC 3220, Australia \\ Correspondence should be addressed to Fuyi Yao; fy.yao@cqu.edu.cn
}

Received 22 February 2021; Revised 2 April 2021; Accepted 20 April 2021; Published 3 May 2021

Academic Editor: Loke Foong

Copyright (C) 2021 Yingbo Ji et al. This is an open access article distributed under the Creative Commons Attribution License, which permits unrestricted use, distribution, and reproduction in any medium, provided the original work is properly cited.

\begin{abstract}
The defect in quality caused by the noncompactness of sleeve grouting has become the main obstacle restricting the further implementation of the prefabricated building in China. Studies have been conducted to explore the influencing factors of inadequate grouting; however, few studies attempt to investigate the complex interrelationship and lack of systematic cognition among these factors. To fill this gap, this study conducted a comprehensive literature review to collect the influencing factors of sleeve grouting and verified the reliability of these factors using the combined methods of brainstorming and semistructured expert discussion. A total of 18 key factors were identified and determined. The structural interpretation model (SIM) and Matrice d'Impacts Croisés Multiplication Appliquée à un Classement (MICMAC) approaches were then used to analyze, depict, and explain the internal relationships between the factors. The results indicate that all factors were classified into six levels, among which poor responsibility of supervisors and weather conditions are the most basic factors, while grouting speed and a loosesealing rubber plug are the most important factors. Finally, a three-level control strategy was proposed to improve the compactness quality of sleeve grouting. The research findings provide valuable guidelines for managers to eliminate the grouting quality defect and to further the development of prefabricated buildings in China.
\end{abstract}

\section{Introduction}

In recent years, prefabricated buildings have been widely adopted in China due to their preferable characteristics in the construction stage compared to the traditional cast-inplace construction [1-4], which is mainly assembled on-site using prefabricated components that are connected using the vertical sleeve method [5-8]. The specific grouting process flow for prefabricated node connections is as follows: the reinforcement of the butt joint is conducted in the sleeve; then, the rapidly hardening nonshrinkage grouting material is injected to ensure the reinforcement connection of the upper and lower components. However, quality defects for sleeve grouting commonly exist in practical construction engineering that has directly impacted the bearing and deformation capacity of the components [9-11], thereby compromising the whole prefabricated building [12]. Zhao et al. [13] observed that the bearing capacity can be reduced by up to $30 \%$ when a defect in grouting quality occurs [14]. Therefore, the construction of a prefabricated building using sleeve grouting as the main component connection method must follow specific requirements to ensure the connection quality performance [15-17], not only to improve the connection technology [18-20], but also to control the influencing factors of the whole grouting construction process.

China issued the national industry standard, named technical specification for grout sleeve splicing of rebars (No. JGJ 355-2015), requiring that sleeve grouting should be compact, which further emphasizes the importance of process quality control for sleeve grouting. In the proposed research, a practical experiment was conducted to determine the current state of grouting quality [21, 22], and three demonstration prefabricated construction projects were 
selected as the experimental targets located in Tangshan, Beijing, and Haimen. These three cities, located in the north, central, and south of China, were selected for demonstrating the promotion of prefabricated buildings. Taking into account the regional differences, the level of grouting quality of the prefabricated building can be roughly reflected by the experimental results. A kind of redesigned sensor is embedded in the sleeve to collect grouting compactness data [23]. The average algorithm of a normal distribution is applied to calculate the overall quality level, and at least 30 sensors are required to be estimated in each targeted building to ensure the results' accuracy [24]. In each project, the researchers selected at least three buildings for testing. To reduce the error caused by the construction height, experiments were carried out on the lowest floor, the highest floor, and the middle floor of each building. Notably, it was found that the quality problem regarding the insufficient compactness of sleeve grouting is serious (shown in Figure 1). The experiment followed a two-step process. First, when the grouting workers completed the sealing of the grouting mouth, the condition of the sleeve grouting was tested immediately. It was found that the qualification rates of the three sample projects were $93.1 \%$ (P11), 93.10\% (P21), and 89.66\% (P31), respectively. Then, the grouting compactness of the three projects was tested again 30 minutes later, which is the maximum time interval for supplementary grouting before the initial setting of grouting materials specified according to the standards. And it was found that the qualification rates decreased to $48.28 \%$ (P12), 58.62\% (P22), and $62.07 \%$ (P32). The average qualification rate was $56.32 \%$, which is significantly lower than the national compulsory requirements. Thus, it is urgent to determine the causes of grouting quality defects to improve the prefabricated building quality $[16,25]$.

At present, several studies have been conducted to explore sleeve grouting defects. The research focus can be roughly divided into two categories. The first category is the technical route. For example, Zheng et al. [26] proved that grouting defects can reduce the seismic performance of the structure. Kuang et al. [27] found that grouting defects lead to a decrease in bearing capacity, rigidity, and ductility of the assembled concrete columns. Li et al. [28] discovered that grouting defects can lead to peeling damage between the reinforcement and the grouting material, or the reinforcement will be pulled out by a scraping plow. These technical problems continue to be studied and explored $[29,30]$. The second category is the management route, referring to the defect control analysis conducted by exploring the management measures that have been applied [31]. For example, Xiong et al. [32] analyzed the factors influencing the strength of grouting materials. Jin et al. [33] studied the temperature effect on the performance of grouting material. However, based on the literature, most studies lack a systematic cognition for quality defect control, and few studies attempt to investigate the complex interrelationship among these factors.

The proposed study aims to fill this gap of lacking systematic cognition among quality defect factors and their complex interrelationship. A mixed-method approach is

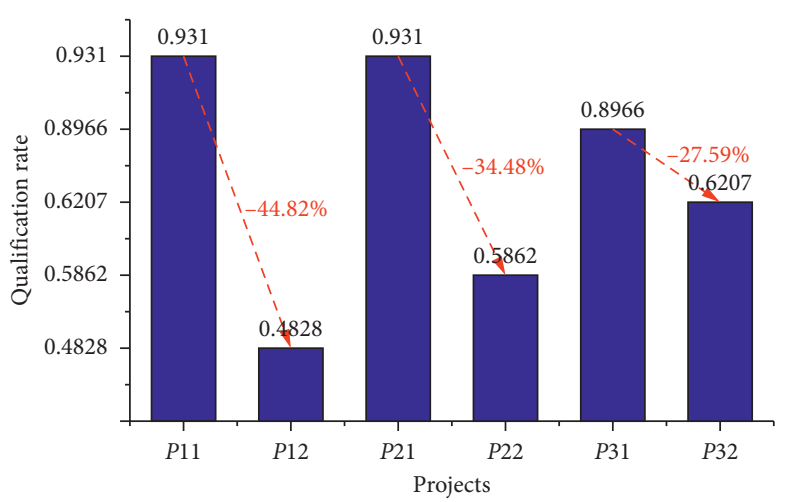

FIgURE 1: Experimental results for the grouting quality.

used for data processing and result analysis combined with Interactive Structural Modeling (ISM) and Matrice d'Impacts Croisés Multiplication Appliquée à un Classement (MICMAC). The objectives of this study are threefold: (1) to identify the critical influencing factors of sleeve grouting defects in China's prefabricated construction industry; (2) to clarify the hierarchical relationship and action path among these factors; and (3) to explore the causes of sleeve grouting defects and propose the quality defect control measures and corresponding management strategies.

\section{Research Method}

A three-step research method is designed to achieve the research objectives (as shown in Figure 2). First, factors affecting the sleeve grouting compactness are identified by using the literature review and analysis approach. Second, key influencing factors are identified utilizing a screening process. A brainstorming session is conducted to determine the definition of each factor. Then, expert interviews are conducted to screen and supplement the preliminary factors, and a final key factors list is determined. Third, the expert rating approach is followed to ascertain experts' perceptions about the interrelationships among the factors. The adjacency matrix and the reachability matrix are constructed using the ISM technique, and the hierarchy structure is depicted after checking the transitivity through the power iteration analysis. Finally, these influencing factors are classified into four categories according to each factor's driving power and dependence power using the MICMAC technique, and the specific reasons, control measures, and management strategies for quality defects are discussed in detail.

2.1. Interpretative Structure Model (ISM). The ISM method, proposed by Warfield in 1974, can be used to analyze the interaction between factors in a complex system. According to the internal relationship, the priority degree and indirect relationship of each factor are determined. In the field of engineering management, ISM is a method often used for factor analysis. ISM has been widely used in the analysis of influencing factors, such as Li and Li [34] who analyzed the driving factors of prefabricated construction by using a 


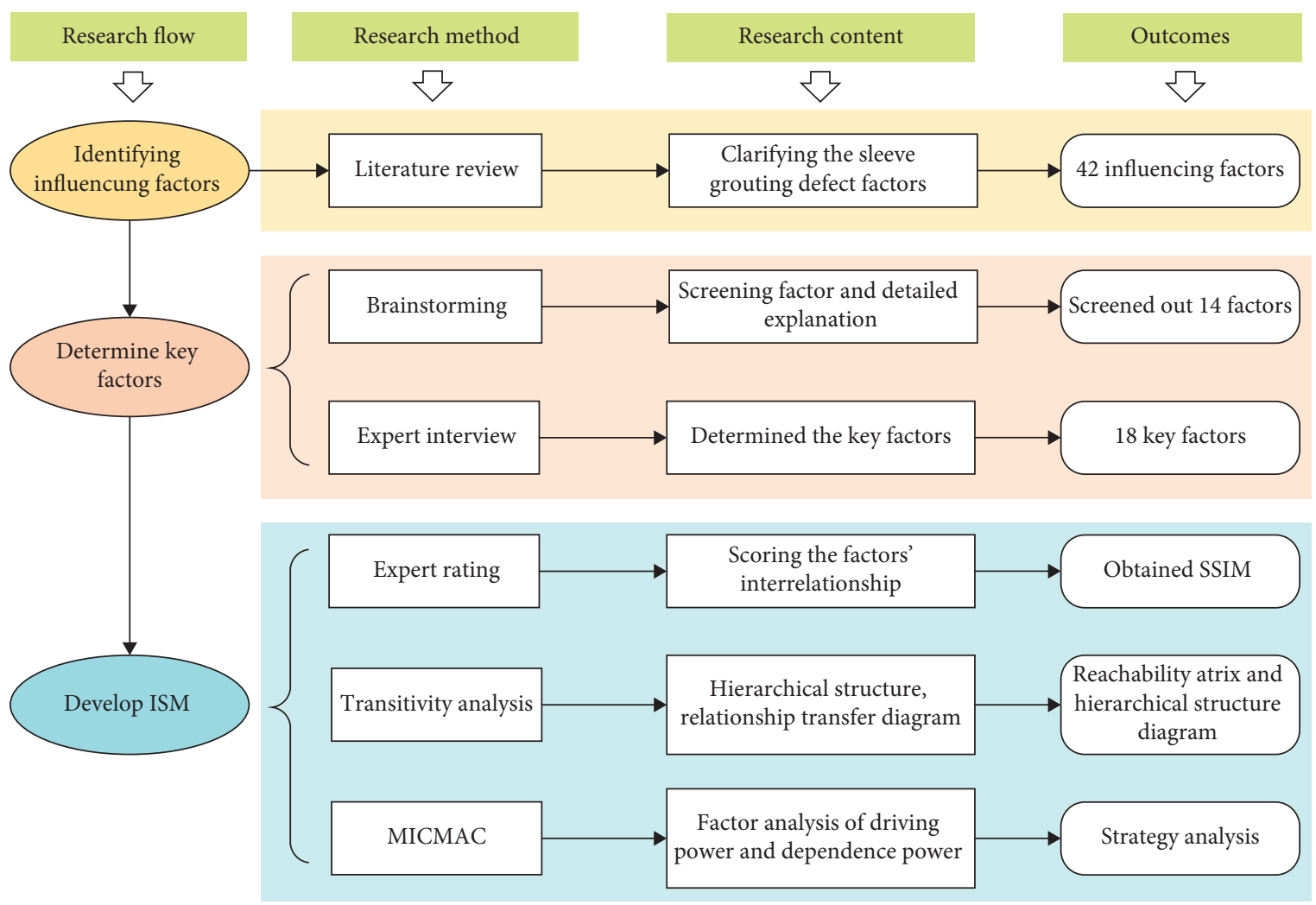

Figure 2: Research framework.

structural interpretation model. Zhou and He [35] analyzed the influencing factors of prefabricated building cost based on the ISM method. Tan [36] used the ISM method to analyze the barriers to Building Information Modeling (BIM) implementation in China's prefabricated construction process. In this study, ISM is applied to analyze the direct binary relationship between the factors influencing the grouting compactness and mapping the conceptual model into a directed graph through the Boolean logic operation. Then, the structure of the grouting quality influential system is presented in the simplest hierarchical topography style without losing the overall system function.

2.2. MICMAC. MICMAC was developed by Duperrin and Godet based on the ISM method and can be used to analyze the relevance and importance of factors in a system. This method can use an action path and hierarchical structure to explore the diffusion of the mutual influence relationship between factors. The rule for classifying factors is dependent upon the driving force and the dependence of factors.

\section{Identification of Key Factors for Sleeve Grouting}

\subsection{Key Factors Identification}

3.1.1. Literature Review. The literature review in this study was conducted based on China National Knowledge Infrastructure (CNKI) and Web of Science databases. The keywords used for the first-round retrieval included "sleeve grouting", "grouting compactness", "factors", and "quality defect", among others. A total of 23 articles were selected as the core literature material pool for influencing factors identification. Finally, 16 preliminary factors shown to influence sleeve grouting defects were collected (shown in Table 1).

3.1.2. Brainstorming. Due to the existing researches focus on analyzing the causes of grouting quality defects from a specific factor perspective, rather than a systematic comprehensive analysis, the identification of initial factors is unorganized and their connotations are unclear. Brainstorming was conducted to discuss the correlation strength between factors and sleeve grouting defects. 18 researchers with expertise in the areas of prefabricated construction, engineering management, or informatization were invited from universities or enterprises to patriciate in the seminar. The basic information for personnel invited to participate in the brainstorming session is presented in Figure 3. The specific explanation for each factor was discussed in detail. Finally, a clear and concise preliminary list was obtained with 16 factors (shown in Table 1), and the identified factors were classified into five categories, including manpower, machine, material, method, and environment (4M1E).

3.1.3. Expert Interview. To further improve the factor list, expert interviews were conducted to remove or supplement factors based on expert experience and knowledge. All of the experts interviewed have more than three years of 
TABLE 1: Background of experts in the third round.

\begin{tabular}{lcccc}
\hline No. & Education & Employment & Major & Position \\
\hline 1 & Master & Construction company & Engineering management & Project manager \\
2 & Doctor & Design company & Civil engineering & Structural engineer \\
3 & Bachelor & Construction company & Civil engineering & Project manager \\
4 & Doctor & University & Structural engineering & Professor \\
5 & Bachelor & Real estate company & Informatization & General manager \\
6 & Doctor & University & Engineering management & Associate professor \\
7 & Bachelor & Component factory & Civil engineering & General manager \\
\hline
\end{tabular}

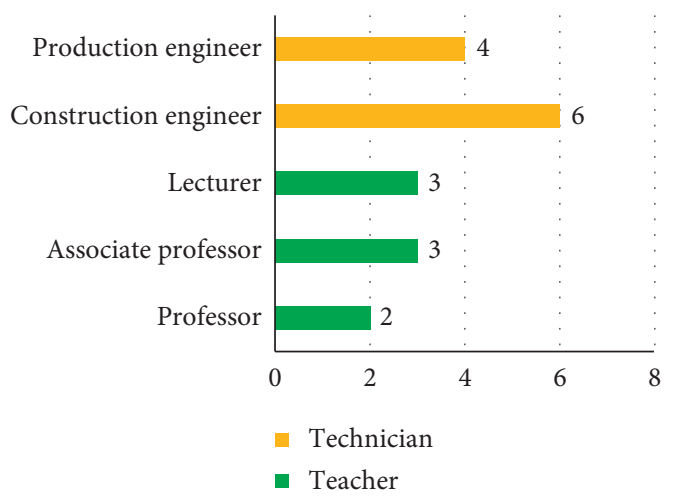

Figure 3: Basic information for brainstorming participants.

experience in prefabricated building construction and guided this study, and the background of experts is shown in Table 1. Valuable observations were obtained from these interviews. On the one hand, experts suggested that technical disclosure ineffective (F3) and understanding deviation of production drawing (F4) should be deleted from the analysis list of grouting quality factors. The reason is that the grouting operation is generally carried out by a specific team with professional training, and the effect of technical disclosure is not obvious; besides, the quality defects caused by understanding deviation of production drawing problems have been eliminated in the component inspection. On the other hand, four critical factors are proposed including weather conditions (F17), mental state of workers (F18), working environment (F19), and grouting speed (F20), which are considered by experts to be ignored easily but have great influence in actual grouting process. The specific reasons are explained in detail in the explanation of the factors. In total, two factors were eliminated and four factors were added. Finally, 18 factors of sleeve grouting defect were established, shown in Table 2.

\subsection{Explanation of Influencing Factors}

F1: poor responsibility of supervisors.

In China, supervisors are usually required to be close to workers. This is not only for video recording, but also to correct any improper equipment operation by workers in real time. However, many supervisors only record the site construction videos and thus fail to correct any issues with worker operations in real time.

F2: lack of experienced workers.
To determine the existing sleeve grouting process in prefabricated building construction, sleeve grouting operation is performed by skilled, experienced workers in a laboratory setting. The demographic of skilled and experienced workers in China's construction industry is in decline. Due to the rapid development of prefabricated buildings in China, it is difficult to ensure that all sleeve grouting workers have qualified relevant experience, which will affect the grouting quality from the perspective of the operational process quality of workers. F3: ineffective technical disclosure.

Construction quality is directly related to the training level of technical disclosure for special construction processes. Before the sleeve grouting operation, the technical personnel is required to provide special operational technical disclosure. The purpose is to make the construction workers have a detailed understanding of the engineering characteristics, technical quality requirements, construction methods, and measures. Effective technical disclosure can facilitate the scientific organization of construction and avoid the occurrence of technical and quality accidents.

F4: understanding deviation of production drawings.

The production personnel have a deviation in the understanding of the drawings provided by the designer, such as the location of the vent hole, the size of the overflow port, etc. This leads to the deviation between the prefabricated wallboard that is produced and the design drawings that are provided, thereby affecting the grouting quality.

F5: inadequate protection measures.

If the protection measures of prefabricated components are not in place, there will be serious quality defect risks. When a prefabricated wall panel is lifted, proper protection must be in place to avoid any damage to the edges. The quality defects caused by transport are usually difficult to repair. Furthermore, the anchoring sealing will become loose, and the sleeve grouting material will begin to leak.

F6: reinforcement connection is not in place.

If the steel reinforcement bars are installed incorrectly, the sleeve passage will be partially blocked thereby causing the problem of grouting noncompactness.

F7: ash not cleared in time.

If the grouting workers fail to clean the grouting channel before the installation of the prefabricated wall, 
TABLE 2: Factors of sleeve grouting quality defects.

\begin{tabular}{|c|c|c|c|c|c|}
\hline Categories & $\begin{array}{l}\text { Factors affecting the occurrence of } \\
\text { quality defects for sleeve grouting }\end{array}$ & Source & $\begin{array}{l}\text { Literature review } \\
\text { and brainstorm }\end{array}$ & $\begin{array}{c}\text { Expert } \\
\text { interview }\end{array}$ & $\begin{array}{c}\text { Key factors } \\
\text { identified }\end{array}$ \\
\hline \multirow{5}{*}{ Manpower } & $\begin{array}{l}\text { Poor responsibility of supervisors } \\
\qquad(\mathrm{F} 1)\end{array}$ & Liu et al. [37] & $\sqrt{ }$ & $\nabla$ & $\sqrt{ }$ \\
\hline & \multirow{2}{*}{$\begin{array}{c}\text { Lack of experienced workers (F2) } \\
\text { Technical disclosure ineffective } \\
\text { (F3) }\end{array}$} & Zhang [38], Qiu and Qian [39], & $\sqrt{ }$ & $\nabla$ & $\sqrt{ }$ \\
\hline & & Li et al. [40], Li and $\mathrm{Hu}[41]$ & $\sqrt{ }$ & 凶 & - \\
\hline & $\begin{array}{l}\text { Understanding deviation of } \\
\text { production drawings (F4) }\end{array}$ & Wang et al. [42] & $\sqrt{ }$ & $\bigotimes$ & - \\
\hline & Mental state of workers (F18) & Interview & - & $\sqrt{ }$ & $\sqrt{ }$ \\
\hline Machine & $\begin{array}{l}\text { Poor mechanical performance of } \\
\text { grouting (F12) }\end{array}$ & Zheng et al. [43] & $\sqrt{ }$ & $\sqrt{ }$ & $\sqrt{ }$ \\
\hline \multirow{3}{*}{ Material } & $\begin{array}{c}\text { Quality problems of raw grouting } \\
\text { materials (F9) }\end{array}$ & $\begin{array}{l}\text { Huang et al. [44], Huang [45], Gao } \\
\text { and Zhang [46], Chen et al. [47], } \\
\text { Wang et al. }[42,46]\end{array}$ & $\sqrt{ }$ & $\square$ & $\sqrt{ }$ \\
\hline & $\begin{array}{l}\text { Incomplete exhaust after standing } \\
\qquad(\mathrm{F} 10)\end{array}$ & $\begin{array}{l}\text { Ma et al. [48], } \mathrm{Li} \text { and } \mathrm{Hu}[41], \text { Zheng } \\
\text { et al. [26] }\end{array}$ & $\sqrt{ }$ & $\square$ & $\sqrt{ }$ \\
\hline & $\begin{array}{c}\text { Inadequate fluidity of grouting } \\
\text { material (F11) }\end{array}$ & Yang et al. [49], Huang et al. [44] & $\sqrt{ }$ & $\square$ & $\sqrt{ }$ \\
\hline \multirow{7}{*}{ Method } & \multirow{2}{*}{$\begin{array}{l}\text { Joint sealing is not tight (F8) } \\
\text { Reinforcement connection is not } \\
\text { in place (F6) }\end{array}$} & \multirow{3}{*}{$\begin{array}{l}\text { Li and } \mathrm{Hu} \text { [41], Huang [50] } \\
\text { Wang, et al. [42], Yan [51], Alam, } \\
\text { et al. [52], Alam et al. [53] } \\
\text { Zhang [38], Qiu and Qian [39], Li } \\
\text { and Hu [41], Yan [51] }\end{array}$} & $\sqrt{ }$ & $\nabla$ & $\sqrt{ }$ \\
\hline & & & $\sqrt{ }$ & $\square$ & $\sqrt{ }$ \\
\hline & $\begin{array}{l}\text { The grouting process is not } \\
\text { standardized (F13) }\end{array}$ & & $\sqrt{ }$ & $\square$ & $\sqrt{ }$ \\
\hline & $\begin{array}{l}\text { Construction technology with } \\
\text { insufficient accuracy (F14) }\end{array}$ & Xue and Tan $[54]$ & $\sqrt{ }$ & $\nabla$ & $\sqrt{ }$ \\
\hline & \multirow{2}{*}{$\begin{array}{l}\text { Loose-sealing rubber plug (F15) } \\
\text { Lack of auxiliary technology } \\
\text { application (F16) }\end{array}$} & Li et al. [28] & $\sqrt{ }$ & $\square$ & $\sqrt{ }$ \\
\hline & & Gao et al. [55] & $\sqrt{ }$ & $\nabla$ & $\sqrt{ }$ \\
\hline & Grouting speed (F20) & Interview & - & $\sqrt{ }$ & $\sqrt{ }$ \\
\hline \multirow{4}{*}{ Environment } & $\begin{array}{l}\text { Inadequate protection measures } \\
\text { (F5) }\end{array}$ & Zhang [38], $\mathrm{Li}$ and $\mathrm{Hu}[41]$ & $\sqrt{ }$ & $\nabla$ & $\sqrt{ }$ \\
\hline & Ash not cleared in time (F7) & $\begin{array}{l}\text { Zhang [38], Li and Chen [56], Huang } \\
{[50]}\end{array}$ & $\sqrt{ }$ & $\nabla$ & $\sqrt{ }$ \\
\hline & Working environment (F19) & Interview & - & $\sqrt{ }$ & $\sqrt{ }$ \\
\hline & Weather condition (F17) & Interview & - & $\sqrt{ }$ & $\sqrt{ }$ \\
\hline
\end{tabular}

Note. " $\vee "=$ agree, " $\square$ " = agree in the second round, " $\nabla "=$ disagree in the second round, and "-"= none existed.

the channel becomes blocked with ash when the grouting channel is stacked and stored on-site, thereby impacting the grouting process.

F8: joint sealing is not tight.

If the joints are not sealed tightly after the installation of the prefabricated wallboard is completed, the grouting materials will leak.

F9: quality problems of grouting materials.

Quality problems exist for the grouting material itself, such as the strength value at 15 minutes or 30 minutes. After 15 minutes of grouting, the degree of hardening will affect the degree of grouting compactness.

F10: incomplete exhaust after standing.

According to the grouting requirements of the technical specification for application of reinforcement sleeve grouting connection, number JGJ 355-2015, after the cementitious grout for rebar sleeve splicing is mixed, it should be allowed to stand for a while (roughly 2 minutes) to wait for any air bubbles to be discharged. However, due to the various complex construction tasks on-site, the workers often conduct the grouting operation directly after the mix of cementitious grout.

F11: inadequate fluidity of grouting material.

The fluidity of grouting material is a key aspect of the grouting compactness. If the grouting material is too thick, it becomes difficult to circulate in the channel; if the grouting material is too thin, it will leak.

F12: poor mechanical performance of grouting.

The performance of the grouting machine determines whether it can provide sufficient power during the grouting process. In the case of poor mechanical performance, the grouting material will either set or settle too quickly.

F13: the grouting process is not standardized.

Because the grouting process is not yet standardized, the grouting workers fail to follow the published construction method when grouting, such as applying 
the rubber plug ahead of time, not applying the plugin time, or not checking the grout density. These irregular operations will lead to grouting noncompactness.

F14: construction technology with insufficient accuracy.

The construction technical method used in sleeve grouting operation is unable to meet the requirements of construction process accuracy, which will lead to grouting quality defects.

F15: loose-sealing rubber plug.

A sealing rubber plug is used to block the grout outlet at one end of the grouting channel in the prefabricated wall. Due to the imbalance of pressure in the grouting channel, the sealing rubber plug that is placed at one end of the channel can be easily displaced, resulting in grouting material leakage.

F16: lack of auxiliary technology application.

Various information technologies have been applied in different areas of construction, such as BIM, sensing technology, image technology, etc. However, there is a lack of technical application in grouting quality control. The application of information technology can effectively assist workers to grasp the quality dynamics.

F17: weather conditions.

Weather conditions have an impact on personnel, machines, and materials in the construction process. For example, high temperature will accelerate the hardening of grouting materials, and precipitation may lead to the absorption of water, resulting in excessive dilution during mixing.

F18: mental state of workers.

The mental state of workers has been shown to directly affect their behavior. A healthy mental state can help workers to maintain concentration and ensure the quality of work. On the contrary, long shifts can reduce the degree of concentration, resulting in a greater potential for safety issues and quality defects.

F19: working environment.

Studies have shown that the work efficiency and accuracy of workers will be affected by the working environment. For example, if a worker is in a noisy working environment, their quality of work will be adversely affected.

F20: grouting speed.

The grouting density is affected by the grouting speed. The too fast grouting speed will cause the pressure in the channel to be too high, which may lead to the leakage of the plug. The too slow grouting speed will cause the pressure in the channel to be too small. Grouting stuffing can not be fully circulated.

\section{Path Analysis Based on the ISM Method}

Structural mapping is generated using the ISM method for analyzing the intricate interconnections among the factors affecting noncompactness in the sleeve grouting process. Five essential steps of ISM methodology are presented in Figure 4 .

4.1. Establishing Correlation Structure. The semistructured interview approach was conducted again to collect experts' views about the interrelationship between 18 key factors. The professions of the interviewed experts include architectural designers, structural engineers, project department personnel, supervisors, and university professors. Each selected interviewee has more than three years of working experience in the construction management of prefabricated buildings, and their rich experience allows them to provide reliable insight into the interaction strength of the various factors. To compare the factors, the survey asked the following question: Do you think factor $i$ directly affects factor $j$. The consistency among all respondents determined the influential relationship between factors. When different judgments were made on the pairwise factors comparison, the principle of "the minority is subordinate to the majority" was adopted. That is, when more than three-quarters of the experts made the same judgment, it was determined that there is an influential relationship between the two factors.

The relationship between factors $i$ and $j$ is expressed using four symbols: (i) $X$ represents that "factor $i$ can cause factor $j$, but not the opposite"; (ii) Y indicates that "factor $j$ can cause factor $i$, but not the opposite"; (iii) W indicates that "factor $i$ and factor $j$ can cause each other"; and (iv) $\mathrm{O}$ represents that "factor $i$ and factor $j$ are not related". The basic data were collected through a semistructured interview. After processing the scores given by different experts, the structural self-interaction matrix (SSIMF) was obtained and the contextual relationship of 18 identified key factors was established, as presented in Table 3.

\subsection{Data Processing and Path Analysis}

4.2.1. Developing Adjacency Matrix. Adjacency matrix was used to express the direct relationship between factors. To calculate the relationship value between the upper and lower levels among the 18 factors, it was necessary to convert SSIM into a binary adjacency matrix, as presented in Table 4 . The specific conversion rules are listed as follows:

(1) If the cell $(i, j)$ entry in the SSIM is $X$, the cell $(i, j)$ entry in the reachability matrix becomes 1 and the cell $(j, i)$ entry becomes 0

(2) If the cell $(i, j)$ entry in the SSIM is $Y$, the cell $(i, j)$ entry in the reachability matrix becomes 0 and the cell $(j, i)$ becomes 1

(3) If the cell $(i, j)$ in the SSIM is $W$, the cell $(i, j)$ entry in the reachability matrix becomes 1 and the cell $(j, i)$ becomes 1

(4) If the cell $(i, j)$ entry in the SSIM is $\mathrm{O}$, the cell $(i, j)$ entry in the reachability matrix becomes 0 and the cell $(j, i)$ also becomes 0 


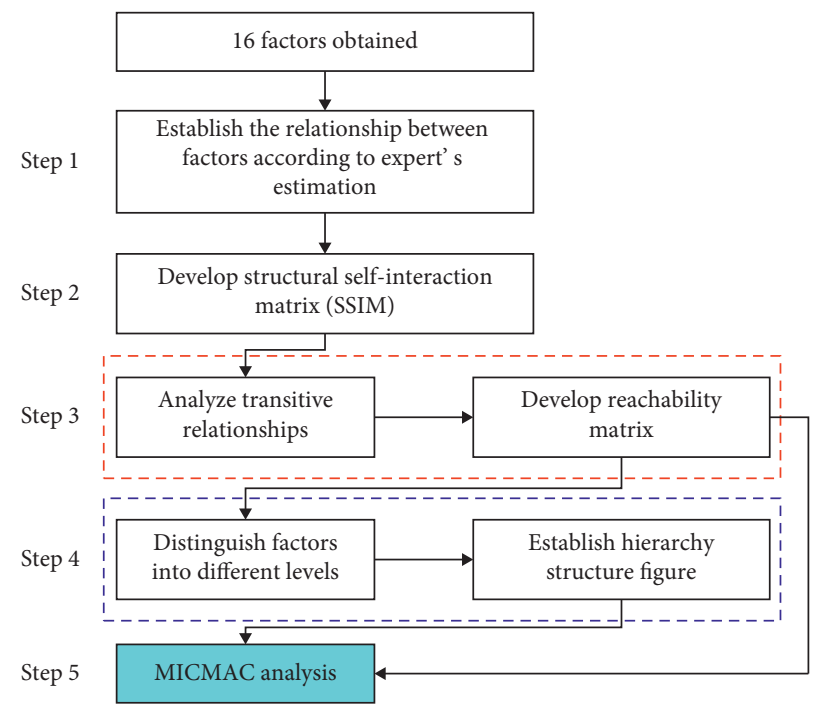

Figure 4: Implementing ISM process.

TABLE 3: The structural self-interaction matrix (SSIM).

\begin{tabular}{|c|c|c|c|c|c|c|c|c|c|c|c|c|c|c|c|c|c|c|}
\hline Factors & F20 & F19 & F18 & F17 & F16 & F15 & F14 & F13 & F12 & F11 & F10 & F9 & F8 & F7 & F6 & F5 & $\mathrm{F} 2$ & $\mathrm{~F} 1$ \\
\hline F1 & $\mathrm{X}$ & $\mathrm{O}$ & $\mathrm{X}$ & $\mathrm{O}$ & $\mathrm{O}$ & $\mathrm{X}$ & $\mathrm{O}$ & $\mathrm{X}$ & $\mathrm{O}$ & $\mathrm{O}$ & $\mathrm{X}$ & $\mathrm{O}$ & $\mathrm{X}$ & $\mathrm{X}$ & $\mathrm{O}$ & $\mathrm{X}$ & $\mathrm{X}$ & - \\
\hline F2 & $\mathrm{X}$ & $\mathrm{O}$ & $\mathrm{O}$ & $\mathrm{O}$ & $\mathrm{Y}$ & $\mathrm{X}$ & $\mathrm{Y}$ & $\mathrm{X}$ & $\mathrm{X}$ & $\mathrm{X}$ & $\mathrm{X}$ & $\mathrm{O}$ & $\mathrm{X}$ & $\mathrm{X}$ & $\mathrm{X}$ & $\mathrm{O}$ & & \\
\hline F5 & $\mathrm{O}$ & $\mathrm{O}$ & $\mathrm{O}$ & $\mathrm{O}$ & $\mathrm{O}$ & $\mathrm{O}$ & $\mathrm{O}$ & $\mathrm{O}$ & $\mathrm{O}$ & $\mathrm{O}$ & $\mathrm{O}$ & $\mathrm{O}$ & $\mathrm{X}$ & $\mathrm{X}$ & $\mathrm{X}$ & - & & \\
\hline F6 & $\mathrm{X}$ & $\mathrm{Y}$ & $\mathrm{Y}$ & $\mathrm{O}$ & $\mathrm{Y}$ & $\mathrm{O}$ & $\mathrm{Y}$ & $\mathrm{O}$ & $\mathrm{O}$ & $\mathrm{O}$ & $\mathrm{O}$ & $\mathrm{O}$ & $\mathrm{O}$ & $\mathrm{O}$ & - & & & \\
\hline F7 & $\mathrm{X}$ & $\mathrm{O}$ & $\mathrm{Y}$ & $\mathrm{O}$ & $\mathrm{O}$ & $\mathrm{O}$ & $\mathrm{O}$ & $\mathrm{O}$ & $\mathrm{O}$ & $\mathrm{X}$ & $\mathrm{O}$ & $\mathrm{O}$ & $\mathrm{X}$ & - & & & & \\
\hline F8 & $\mathrm{X}$ & $\mathrm{Y}$ & $\mathrm{Y}$ & $\mathrm{O}$ & $\mathrm{O}$ & $\mathrm{O}$ & Y & $\mathrm{O}$ & $\mathrm{O}$ & $\mathrm{O}$ & $\mathrm{O}$ & $\mathrm{O}$ & - & & & & & \\
\hline F9 & $\mathrm{X}$ & $\mathrm{O}$ & $\mathrm{O}$ & $\mathrm{O}$ & $\mathrm{O}$ & $\mathrm{O}$ & $\mathrm{O}$ & $\mathrm{O}$ & $\mathrm{O}$ & $\mathrm{X}$ & $\mathrm{X}$ & - & & & & & & \\
\hline F10 & $\mathrm{X}$ & $\mathrm{O}$ & $\mathrm{Y}$ & $\mathrm{O}$ & $\mathrm{O}$ & $\mathrm{X}$ & $\mathrm{O}$ & $\mathrm{O}$ & $\mathrm{Y}$ & $\mathrm{X}$ & - & & & & & & & \\
\hline F11 & $\mathrm{X}$ & $\mathrm{Y}$ & $\mathrm{Y}$ & $\mathrm{O}$ & $\mathrm{Y}$ & $\mathrm{X}$ & $\mathrm{O}$ & $\mathrm{O}$ & $\mathrm{Y}$ & - & & & & & & & & \\
\hline F12 & $\mathrm{O}$ & Y & $\mathrm{O}$ & $\mathrm{Y}$ & Y & $\mathrm{X}$ & $\mathrm{X}$ & $\mathrm{O}$ & & & & & & & & & & \\
\hline F13 & $\mathrm{X}$ & Y & Y & Y & $\mathrm{Y}$ & $\mathrm{X}$ & $\mathrm{Y}$ & - & & & & & & & & & & \\
\hline F14 & $\mathrm{X}$ & $\mathrm{X}$ & $\mathrm{O}$ & $\mathrm{O}$ & W & $\mathrm{X}$ & - & & & & & & & & & & & \\
\hline F15 & W & Y & $\mathrm{Y}$ & $\mathrm{O}$ & $\mathrm{O}$ & - & & & & & & & & & & & & \\
\hline F16 & $\mathrm{X}$ & $\mathrm{X}$ & $\mathrm{O}$ & $\mathrm{O}$ & - & & & & & & & & & & & & & \\
\hline F17 & $\mathrm{O}$ & $\mathrm{O}$ & $\mathrm{X}$ & - & & & & & & & & & & & & & & \\
\hline F18 & $\mathrm{X}$ & Y & - & & & & & & & & & & & & & & & \\
\hline F19 & $\mathrm{X}$ & - & & & & & & & & & & & & & & & & \\
\hline F20 & - & & & & & & & & & & & & & & & & & \\
\hline
\end{tabular}

Note. The lower-right area corresponds to the relational content in the upper-left area.

TABle 4: Adjacency matrix of 18 key factors.

\begin{tabular}{|c|c|c|c|c|c|c|c|c|c|c|c|c|c|c|c|c|c|c|}
\hline Factors & $\mathrm{F} 1$ & F2 & F5 & F6 & F7 & F8 & F9 & F10 & F11 & F12 & F13 & F14 & F15 & F16 & $\mathrm{F} 17$ & F18 & F19 & F20 \\
\hline $\mathrm{F} 1$ & 0 & 1 & 1 & 0 & 1 & 1 & 0 & 1 & 0 & 0 & 1 & 0 & 1 & 0 & 0 & 1 & 0 & 1 \\
\hline $\mathrm{F} 2$ & 0 & 0 & 0 & 1 & 1 & 1 & 0 & 1 & 1 & 1 & 1 & 0 & 1 & 0 & 0 & 0 & 0 & 1 \\
\hline F5 & 0 & 0 & 0 & 1 & 1 & 1 & 0 & 0 & 0 & 0 & 0 & 0 & 0 & 0 & 0 & 0 & 0 & 0 \\
\hline F6 & 0 & 0 & 0 & 0 & 0 & 0 & 0 & 0 & 0 & 0 & 0 & 0 & 0 & 0 & 0 & 0 & 0 & 1 \\
\hline F7 & 0 & 0 & 0 & 0 & 0 & 1 & 0 & 0 & 1 & 0 & 0 & 0 & 0 & 0 & 0 & 0 & 0 & 1 \\
\hline F8 & 0 & 0 & 0 & 0 & 0 & 0 & 0 & 0 & 0 & 0 & 0 & 0 & 0 & 0 & 0 & 0 & 0 & 1 \\
\hline F9 & 0 & 0 & 0 & 0 & 0 & 0 & 0 & 1 & 1 & 0 & 0 & 0 & 0 & 0 & 0 & 0 & 0 & 1 \\
\hline F10 & 0 & 0 & 0 & 0 & 0 & 0 & 0 & 0 & 1 & 0 & 0 & 0 & 1 & 0 & 0 & 0 & 0 & 1 \\
\hline $\mathrm{F} 12$ & 0 & 0 & 0 & 0 & 0 & 0 & 0 & 0 & 0 & 0 & 0 & 0 & 1 & 0 & 0 & 0 & 0 & 1 \\
\hline F11 & 0 & 0 & 0 & 0 & 0 & 0 & 0 & 1 & 1 & 0 & 0 & 1 & 1 & 0 & 0 & 0 & 0 & 0 \\
\hline F13 & 0 & 0 & 0 & 0 & 0 & 0 & 0 & 0 & 0 & 0 & 0 & 0 & 1 & 0 & 0 & 0 & 0 & 1 \\
\hline F14 & 0 & 1 & 0 & 1 & 0 & 1 & 0 & 0 & 0 & 0 & 1 & 0 & 1 & 1 & 0 & 0 & 1 & 1 \\
\hline F15 & 0 & 0 & 0 & 0 & 0 & 0 & 0 & 0 & 0 & 0 & 0 & 0 & 0 & 0 & 0 & 0 & 0 & 1 \\
\hline F16 & 0 & 1 & 0 & 1 & 0 & 0 & 0 & 0 & 1 & 1 & 1 & 1 & 0 & 0 & 0 & 0 & 1 & 1 \\
\hline F17 & 0 & 0 & 0 & 0 & 0 & 0 & 0 & 0 & 0 & 1 & 1 & 0 & 0 & 0 & 0 & 1 & 0 & 0 \\
\hline F18 & 0 & 0 & 0 & 1 & 1 & 1 & 0 & 1 & 1 & 0 & 1 & 0 & 1 & 0 & 0 & 0 & 0 & 1 \\
\hline F19 & 0 & 0 & 0 & 1 & 0 & 1 & 0 & 0 & 1 & 1 & 1 & 0 & 1 & 0 & 0 & 1 & 0 & 1 \\
\hline F20 & 0 & 0 & 0 & 0 & 0 & 0 & 0 & 0 & 0 & 0 & 0 & 0 & 1 & 0 & 0 & 0 & 0 & 0 \\
\hline
\end{tabular}


4.2.2. Developing Reachability Matrix. According to the specific conversion rules, an initial adjacency was obtained by transforming SSIM into a binary matrix. The final reachability matrix was generated by calculating the indirect transferability of the factors based on a MATLAB program, as presented in Figure 5. The final reachable matrix can be obtained, as presented in Table 5 . In this table, digit 1 indicates that a direct relationship exists between the two factors, while $1 *$ represents an indirect relationship. For example, $\mathrm{F} 1 \longrightarrow \mathrm{F} 5$ and $\mathrm{F} 5 \longrightarrow \mathrm{F} 6$. Although there is no direct relationship between $\mathrm{F} 1$ and F6, it can be considered that, under the influence of F5, F1 can indirectly affect F6; thus $1 *$ can be reconstructed as $\mathrm{F} 1 \longrightarrow \mathrm{F} 6$.

4.2.3. Developing Hierarchy Structure. Based on the final reachability matrix, the hierarchical division was determined by the reachability set and antecedent set of each factor. The former indicates that a factor directly or indirectly influences other factors, while the latter indicates that the factor is directly or indirectly affected by other factors. Additionally, their intersection can be obtained. The detailed steps for developing a hierarchy structure are as follows: (i) if the intersection and reachability set contain the same factors, then these factors are located at the highest influence structure point of the whole system. This indicates that these factors are likely to be affected by other factors. (ii) Once the top-level factor is identified, it will be removed from the accessibility setting. (iii) The identified process is repeated to obtain factors at the next level until all of the factors are placed at this level. The 18 key factors were divided into 6 levels, and the results of level groupings are presented in Table 6.

A simple analysis is presented as follows:

(1) At the lowest level, poor responsibility of supervisors (F1) and weather conditions (F17) are the most basic factors in the structural level. This indicates that the least influential cause for grouting defects is the subjective reason of personnel responsibility and the objective influence of the external environment.

(2) Lack of experienced workers (F2), the poor mechanical performance of grouting (F12), construction technology with insufficient accuracy (F14), lack of auxiliary technology application (F16), and working environment (F19) constitute the fifth level concerning the technical capability factor. This factor primarily represents the professional ability level, construction process level, and technology application level.

(3) The fourth and third levels constitute the indirect influencing factors of grouting quality defects, and it was observed that a progressive internal relationship between the two levels also exists. For example, inadequate protection measures (F5) and quality problems of raw grouting material (F9) belong to the early preparation stage; and ash not cleared in time (F7) and incomplete exhaust after standing (F10) can be affected by F5 and F9, respectively, which are in closer proximity to the specific grouting process.
(4) The factors found in the second and first levels directly lead to grouting quality defects, and the probability approaches 1 as the hierarchy increases. Furthermore, reinforcement connection not in place (F6), joint sealing not tight (F8), inadequate fluidity of grouting material (F11), and grouting process not standardized (F13) will directly affect the loose-sealing rubber plug (F15) and grouting speed (F20) in the first level.

(5) Some cross-level factor interactions also exist and are mainly caused by human factors.

Based on the level partitioning and adjacency matrix, the influence chain graph is drawn as presented in Figure 6. An arrow pointing from factor I to factor $J$ indicates that I can affect $J$, while a two-way arrow indicates the mutual influence. Besides, it is confusing to include all of the interrelationships in this way. Thus, to optimize the visualization of the transmission relationships between factors, some relationships can be replaced or omitted by adopting the path integral approach. For example, since F1 $\longrightarrow$ F19, F1 $\longrightarrow$ $\mathrm{F} 18$, and $\mathrm{F} 19 \longrightarrow \mathrm{F} 18$, the direct lines between $\mathrm{F} 1$ and $\mathrm{F} 18$ can be omitted, and the interrelationships can be described as $\mathrm{F} 1 \longrightarrow \mathrm{F} 19 \longrightarrow \mathrm{F} 18$.

By combining the graph with the final reachability matrix, the relationships among 18 factors of the ISM model can be obtained, as illustrated in Figure 7.

4.2.4. MICMAC Analysis. The driving force and dependence force of each factor can be calculated based on the reachability matrix, forming a two-dimensional MICMAC diagram, as illustrated in Figure 8. Four groups are formed, that is, (i) the independent variables with low driving force and dependence, (ii) the dependent variables with low driving force but high dependence, (iii) the driving variables with high driving force but low dependence, and (iv) the related variables with the high driving force and dependence. In general, the strong dependence of a factor indicates that its solution depends on the solution of other factors, while the strong driving force indicates that the solution of the factor can help resolve other factors.

It can be observed that all factors are divided into three categories, including driver variables, autonomous variables, and dependent variables, as shown in Figure 6, and there is no relay factor. (i) F1, F2, F12, F14, F16, F17, and F19 are driving factors; (ii) F5, F9, F13, and F18 are self-influencing factors; (iii) F6, F7, F8, F11, F15, and F20 are dependent factors. The factors belonging to different levels are marked with different colors, as shown in Figure 6. It can also be observed that the distribution of all factors indicates a downward trend from the upper-left corner to the lowerright corner, which is consistent with the ISM model structure diagram. The factors at the bottom of the structure have strong driving power and low dependence, while the factors at the top level have stronger dependence and lower driving power. Different factors have different parameter characteristics, which determine that different corresponding strategies need to be formulated in the process of eliminating quality defects. 


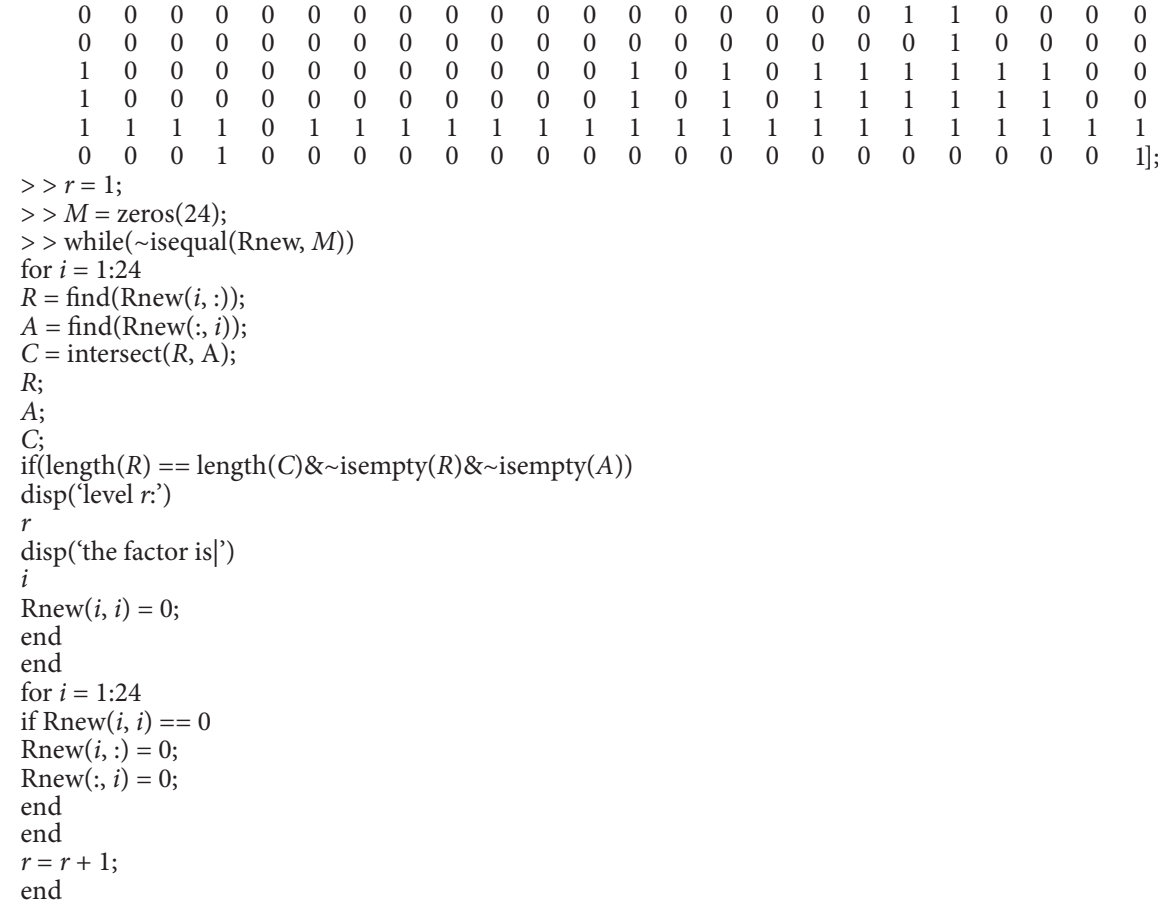

Figure 5: The MATLAB program (including a code example).

TABLE 5: Reachability matrix (including initial and final).

\begin{tabular}{|c|c|c|c|c|c|c|c|c|c|c|c|c|c|c|c|c|c|c|c|}
\hline Factors & F1 & $\mathrm{F} 2$ & F5 & F6 & F7 & F8 & F9 & F10 & F11 & $\mathrm{F} 12$ & F13 & F14 & F15 & F16 & F17 & F18 & F19 & F20 & Dri. \\
\hline F1 & 1 & 1 & 1 & $1^{*}$ & 1 & 1 & 0 & 1 & $1^{*}$ & $1^{*}$ & 1 & $1^{*}$ & 1 & $1^{*}$ & 0 & 1 & $1^{*}$ & 1 & 16 \\
\hline F2 & 0 & 1 & 0 & 1 & 1 & 1 & 0 & 1 & 1 & 1 & 1 & $1^{*}$ & 1 & $1^{*}$ & 0 & $1^{*}$ & $1^{*}$ & 1 & 14 \\
\hline F5 & 0 & 0 & 1 & 1 & 1 & 1 & 0 & 0 & $1^{*}$ & 0 & 0 & 0 & $1^{*}$ & 0 & 0 & 0 & 0 & $1^{*}$ & 7 \\
\hline F6 & 0 & 0 & 0 & 1 & 0 & 0 & 0 & 0 & 0 & 0 & 0 & 0 & $1^{*}$ & 0 & 0 & 0 & 0 & 1 & 3 \\
\hline F7 & 0 & 0 & 0 & 0 & 1 & 1 & 0 & 0 & 1 & 0 & 0 & 0 & $1^{*}$ & 0 & 0 & 0 & 0 & 1 & 5 \\
\hline F8 & 0 & 0 & 0 & 0 & 0 & 1 & 0 & 0 & 0 & 0 & 0 & 0 & $1^{*}$ & 0 & 0 & 0 & 0 & 1 & 3 \\
\hline F9 & 0 & 0 & 0 & 0 & 0 & 0 & 1 & 1 & 1 & 0 & 0 & 0 & $1^{*}$ & 0 & 0 & 0 & 0 & 1 & 5 \\
\hline F10 & 0 & 0 & 0 & 0 & 0 & 0 & 0 & 1 & 1 & 0 & 0 & 0 & 1 & 0 & 0 & 0 & 0 & 1 & 4 \\
\hline F11 & 0 & 0 & 0 & 0 & 0 & 0 & 0 & 0 & 1 & 0 & 0 & 0 & 1 & 0 & 0 & 0 & 0 & 1 & 3 \\
\hline F12 & 0 & $1^{*}$ & 0 & $1^{*}$ & $1^{*}$ & $1^{*}$ & 0 & 1 & 1 & 1 & $1^{*}$ & 1 & 1 & $1^{*}$ & 0 & $1^{*}$ & $1^{*}$ & $1^{*}$ & 14 \\
\hline F13 & 0 & 0 & 0 & 0 & 0 & 0 & 0 & 0 & 0 & 0 & 1 & 0 & 1 & 0 & 0 & 0 & 0 & 1 & 3 \\
\hline F14 & 0 & 1 & 0 & 1 & $1^{*}$ & 1 & 0 & $1^{*}$ & $1^{*}$ & $1^{*}$ & 1 & 1 & 1 & 1 & 0 & $1^{*}$ & 1 & 1 & 14 \\
\hline F15 & 0 & 0 & 0 & 0 & 0 & 0 & 0 & 0 & 0 & 0 & 0 & 0 & 1 & 0 & 0 & 0 & 0 & 1 & 2 \\
\hline F16 & 0 & 1 & 0 & 1 & $1^{*}$ & $1^{*}$ & 0 & $1^{*}$ & 1 & 1 & 1 & 1 & $1^{*}$ & 1 & 0 & $1^{*}$ & 1 & 1 & 14 \\
\hline F17 & 0 & $1^{*}$ & 0 & $1^{*}$ & $1^{*}$ & $1^{*}$ & 0 & $1^{*}$ & $1^{*}$ & 1 & 1 & $1^{*}$ & $1^{*}$ & $1^{*}$ & 1 & 1 & $1^{*}$ & $1^{*}$ & 15 \\
\hline F18 & 0 & 0 & 0 & 1 & 1 & 1 & 0 & 1 & 1 & 0 & 1 & 0 & 1 & 0 & 0 & 1 & 0 & 1 & 9 \\
\hline F19 & 0 & $1^{*}$ & 0 & 1 & $1^{*}$ & 1 & 0 & $1^{*}$ & 1 & 1 & 1 & $1^{*}$ & 1 & $1^{*}$ & 0 & 1 & 1 & 1 & 14 \\
\hline F20 & 0 & 0 & 0 & 0 & 0 & 0 & 0 & 0 & 0 & 0 & 0 & 0 & 1 & 0 & 0 & 0 & 0 & 1 & 2 \\
\hline Dep & 1 & 7 & 2 & 10 & 10 & 11 & 1 & 10 & 13 & 7 & 9 & 7 & 18 & 7 & 1 & 8 & 7 & 18 & \\
\hline
\end{tabular}

TABLE 6: Results of grouping levels.

\begin{tabular}{|c|c|c|c|c|}
\hline Factors & Reachability set & Antecedent set & Intersection & Level \\
\hline F1 & $\begin{array}{l}\text { F1; F2; F5; F6; F7; F8; F10; F11; F12; F13; F14; } \\
\text { F15; F16; F18; F19; F20 }\end{array}$ & F1 & F1 & VI \\
\hline F2 & $\begin{array}{c}\text { F2; F6; F7; F8; F10; F11; F12; F13; F14; F15; F16; } \\
\text { F18; F19; F20 }\end{array}$ & F1; F2; F12; F14; F16; F17; F19 & $\begin{array}{l}\text { F2; F12; F14; F16; } \\
\text { F19 }\end{array}$ & $\mathrm{V}$ \\
\hline F5 & F5; F6; F7; F8; F11; F15; F20 & F1; F5 & F5 & IV \\
\hline F6 & F6; F15; F20 & F1; F2; F5; F6; F12; F14; F16; F17; F18; F19 & F6 & II \\
\hline F7 & F7; F8; F11; F15; F20 & F1; F2; F5; F7; F12; F14; F16; F17; F18; F19 & F7 & III \\
\hline F8 & F8; F15; F20 & F1; F2; F5; F7; F8; F12; F14; F16; F17; F18; F19 & F8 & II \\
\hline F9 & F9; F10; F11; F15; F20 & F9 & F9 & IV \\
\hline F10 & F10; F11; F15; F20 & F1; F2; F9; F10; F12; F14; F16; F17; F18; F19 & F10 & III \\
\hline
\end{tabular}


TABLE 6: Continued.

\begin{tabular}{|c|c|c|c|c|}
\hline Factors & Reachability set & Antecedent set & Intersection & Level \\
\hline F11 & F11; F15; F20 & $\begin{array}{l}\text { F1; F2; F5; F7; F9; F10; F11; F12; F14; F16; F17; F18; } \\
\text { F19 }\end{array}$ & F11 & II \\
\hline F12 & $\begin{array}{c}\text { F2; F6; F7; F8; F10; F11; F12; F13; F14; F15; F16; } \\
\text { F18; F19; F20 }\end{array}$ & F1; F2; F12; F14; F16; F17; F19 & $\begin{array}{l}\text { F2; F12; F14; F16; } \\
\text { F19 }\end{array}$ & $\mathrm{V}$ \\
\hline F13 & F13; F15; F20 & F1; F2; F12; F13; F14; F16; F17; F18; F19 & F13 & II \\
\hline F14 & $\begin{array}{c}\text { F2; F6; F7; F8; F10; F11; F12; F13; F14; F15; F16; } \\
\text { F18; F19; F20 }\end{array}$ & F1; F2; F12; F14; F16; F17; F19 & $\begin{array}{l}\text { F2; F12; F14; F16; } \\
\text { F19 }\end{array}$ & $\mathrm{V}$ \\
\hline F15 & F15; F20 & $\begin{array}{c}\text { F1; F2; F5; F6; F7; F8; F9; F10; F11; F12; F13; F14; } \\
\text { F15; F16; F17; F18; F19; F20 }\end{array}$ & F15; F20 & I \\
\hline F16 & $\begin{array}{c}\text { F2; F6; F7; F8; F10; F11; F12; F13; F14; F15; F16; } \\
\text { F18; F19; F20 }\end{array}$ & F1; F2; F12; F14; F16; F17; F19 & $\begin{array}{l}\text { F2; F12; F14; F16; } \\
\text { F19 }\end{array}$ & $\mathrm{V}$ \\
\hline F17 & $\begin{array}{c}\text { F2; F6; F7; F8; F10; F11; F12; F13; F14; F15; F16; } \\
\text { F17; F18; F19; F20 }\end{array}$ & F17 & F17 & VI \\
\hline F18 & F6; F7; F8; F10; F11; F13; F15; F18; F20 & F1; F2; F12; F14; F16; F17; F18; F19 & F18 & IV \\
\hline F19 & $\begin{array}{c}\text { F2; F6; F7; F8; F10; F11; F12; F13; F14; F15; F16; } \\
\text { F18; F19; F20 }\end{array}$ & F1; F2; F12; F14; F16; F17; F19 & $\begin{array}{l}\text { F2; F12; F14; F16; } \\
\text { F19 }\end{array}$ & $\mathrm{V}$ \\
\hline F20 & F15; F20 & $\begin{array}{c}\text { F1; F2; F5; F6; F7; F8; F9; F10; F11; F12; F13; F14; } \\
\text { F15; F16; F17; F18; F19; F20 }\end{array}$ & F15; F20 & I \\
\hline
\end{tabular}

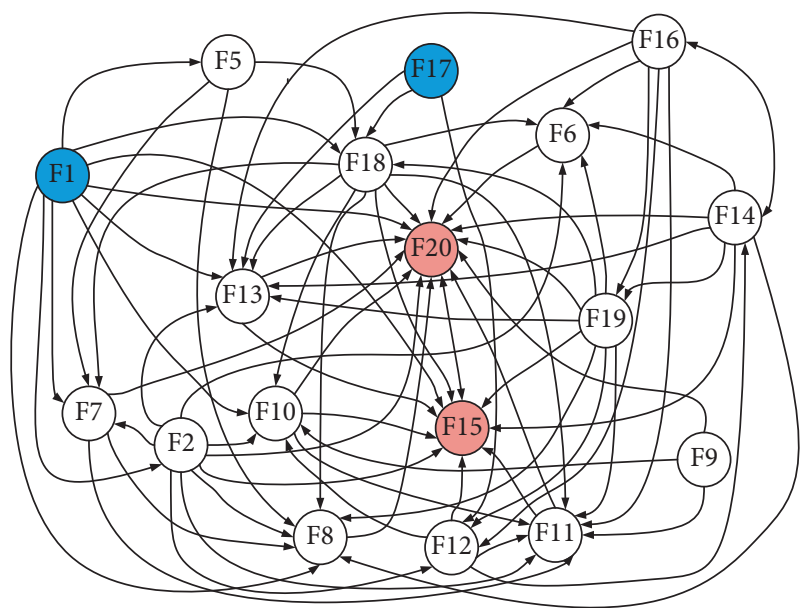

FIGURE 6: Interrelationships among 18 influencing factors.

\section{Discussion}

5.1. Results Analysis. To further analyze the influence mechanism of each factor, a combined approach is proposed to analyze the driving and dependence power based on the MICMAC technique and ISM hierarchy. As a result of the proposed study, the relationships between factors can be understood more effectively, and coping strategies can be formulated.

5.1.1. Driver Variables. F1 and F17 have the highest driving power and are located at the bottom of the ISM structural diagram (Figure 5), which means that the two factors are relatively independent and experience no interference from other factors. Attention should be paid to the grouting process. In practical prefabricated construction, supervision is the most critical part of quality control, and weather conditions are often neglected factors. Although detailed construction rules have been developed, third party supervisors often overlook the environmental impact within the scope of quality control. Currently, video technology is required to be applied in some projects to achieve quality control after a quality control issue and to analyze the irregular behavior of workers.

For the factors F2, F12, F14, F16, and F19, the total driving force index reached 70 , accounting for $48.61 \%$ of the total, and the coverage rate of factors affected reached $77.78 \%$. More attention should be paid to achieving maximum quality improvement benefits with less resource consumption. For example, for F2, it is necessary to increase the professional training of workers and strengthen the management of workers' turnover; for F16, the advanced auxiliary technology can be used for grouting quality control defects, such as the simulation for guiding the construction of BIM technology, the grouting compactness measurement of sensing technology, the detection application of hollow defects in the sleeve using ultrasonic technology, and so on.

5.1.2. Autonomous Variables. The factors for autonomous variables are mainly concentrated in the fourth layer of the ISM and have low driving or dependence power and large dispersion. The mental state of workers (F18) should be taken as a key factor in improving quality and efficiency. Studies have shown that the output of workers who have been working several hours (such as 5 hours) in a row is lower than when they have been given regular breaks. The fatigue level monitoring and health management of workers have been widely applied in the machinery production and craft industry and can be used as references in the prefabricated building construction industry for grouting workers. A reasonable construction plan and more attention to the mental state of workers are important to ensure the quality of grouting operation.

F5 and F9 have lower driving and dependence power. The inadequate protection measures (F5) and quality problems of raw grouting materials (F9) belong to the front end of the influence chain and are relatively independent; 


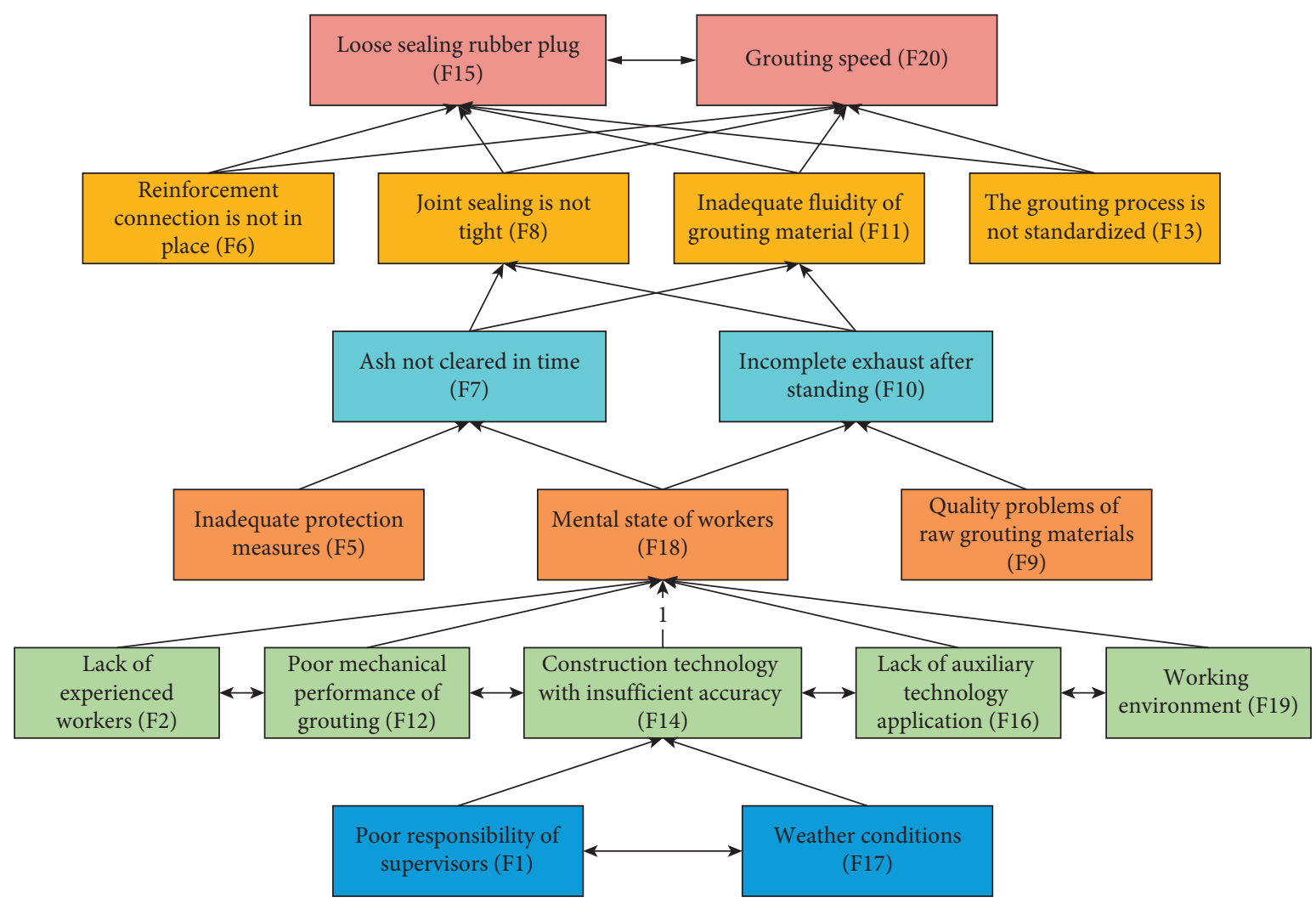

(a)

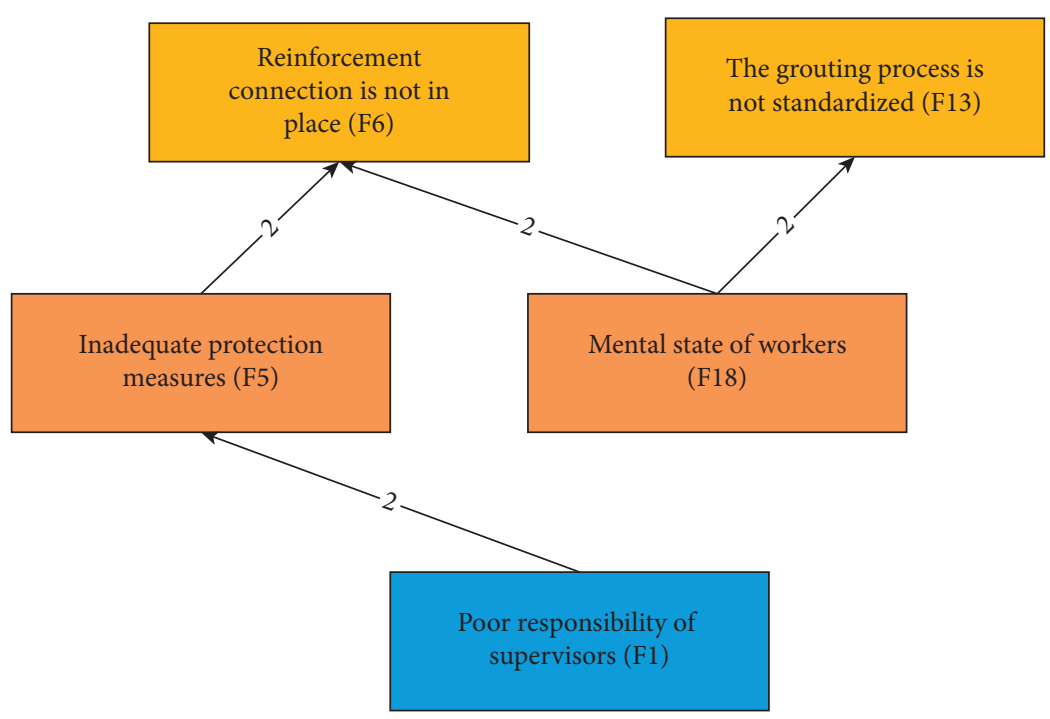

(b)

FIgURE 7: ISM model of factors: (a) first-level diagram; (b) cross-level diagram.

furthermore, these factors can be avoided by adopting some quality inspection measures in advance.

F13 is a specialized transitional factor that changes from passive influence to active influence, while other factors at the same level belong to dependent variables. The unstandardized grouting process mainly refers to the failure to strictly follow the published construction method when grouting, such as plugging the channel ahead of time, not plugging the channel in time, not checking the grout density, etc. The stronger attribute of dependence than driving power indicates a greater influence from other factors, such as the mental state of workers (F18), poor responsibility of supervisors (F1), construction technology with insufficient accuracy (F14), and lack of experience of workers (F2).

5.1.3. Dependent Variables. F6, F8, F11, F7, and F10 derive from different ISM hierarchy; they are dependent variables 


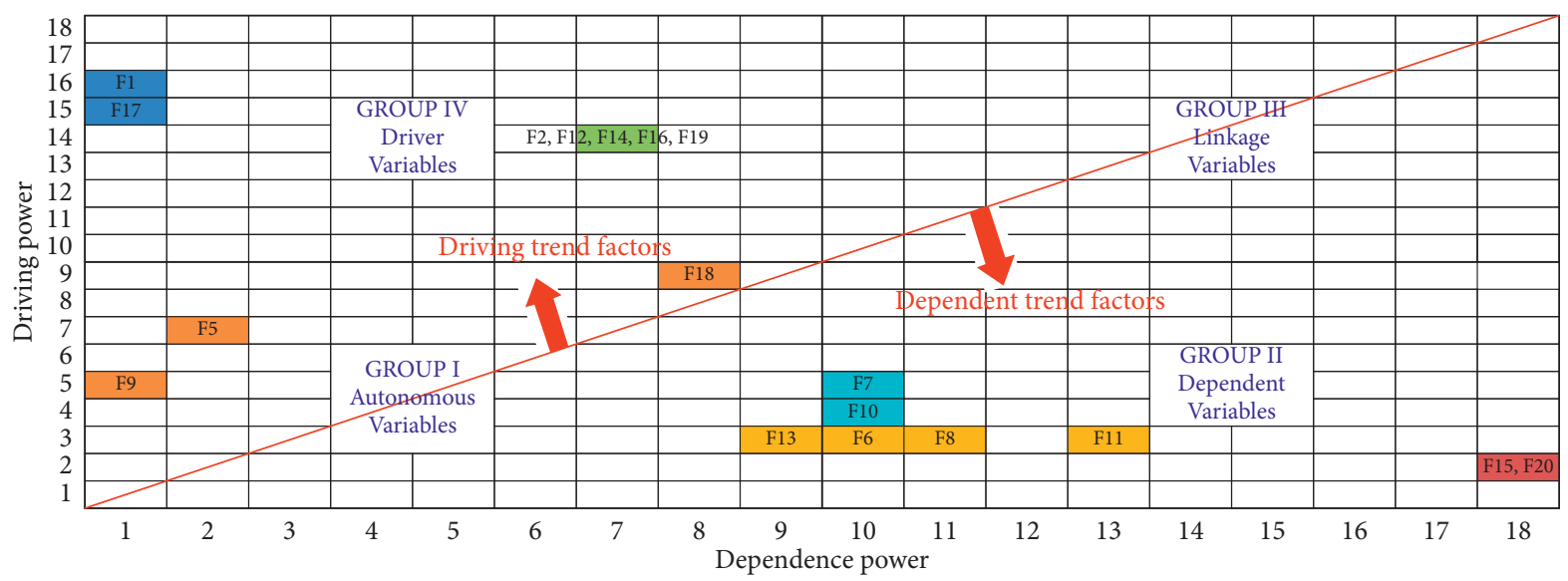

FIgURE 8: Results of MICMAC analysis of influence factors.

but have relatively high driving forces, indicating that their quality problems are dependent upon the resolution of other underlying factors, for example, ash not cleared in time (F7) and need to strengthen protection measures (F5), increase worker experience (F2), enhance the sense of responsibility of quality supervision (F1), and so on. Also, the second-level factors (F6, F8, and F11) and third-level factors (F7 and F10) have an internal connection; for example, inadequate fluidity of grouting material (F11) is related to ash clearing in the component base and grouting port (F7) and the complete standing exhaust of slurry before grouting construction (F10). Therefore, taking these factors into account can not only test whether the quality control of the lower-level factors is effective but also effectively control the upper-level factors.

F15 and F20 are the strongest dependent variables located in the first layer of the ISM hierarchy, where the single dependent power is 18 and driving power is 2 . In the sleeve grouting construction process, the rubber plug that blocks the grouting channel is often removed for some nonstandard operations, and as a result, the grouting material flows out of the channel. Besides, if the grouting speed (F20) is too rapid, a series of quality defects can be caused, such as empty drum, noncompactness, rubber plug loose (F15), among others. In the current construction industry, the effective control of grouting speed (F20) and preventing the rubber plug from falling off (F15) have become the two most critical technical issues. The characterization of highly dependent power indicates that the resolution of the technical issues largely depends on the control of the underlying factors, such as improving the mechanical performance of grouting (F12), applying auxiliary information technology to quality defects at the early warning signs (F16), eliminating adverse effects of the working environment (F19), strengthening the construction process management (F1, F5, F7, F9, F10, etc.), and so on.

5.2. Recommendations. Based on the analysis of the results of this research, the mechanism and implication of each key factor have been clarified. Furthermore, to improve the quality of sleeve grouting construction, a three-level quality control strategy is proposed for the relevant enterprises and technical personnel.

(1) The first level of the control strategy is mainly aimed at the fifth- and sixth-level factors. These factors will not directly lead to grouting defects but will affect other factors. Suggestions are made as follows: (i) the supervisory personnel should be required to improve their sense of responsibility by adopting some regulatory measures. (ii) The impact of weather conditions on construction quality should be emphasized to avoid forced construction in poor conditions in an attempt to accelerate the construction progress. (iii) The environmental conditions will damage any components that are stacked or stored in an exposed area; thus it is necessary to strengthen the protection measures of these components. (iv) In terms of construction capacity improvement, the construction equipment and technology should be continuously updated to improve the construction accuracy, efficiency, and quality, for example, the improved sleeve grouting technology for grouting speed and maintaining a stable pressure in the sleeve to reduce hollowing. (v) The workers should receive training to reach a certain level of professional skills before working on a real construction project; such training should include mastering the operational procedures, being familiar with machine performance, understanding the working environment, and so on.

(2) The second level of the control strategy is aimed at the fourth-level factors. It can be concluded from Figure 5 that these factors are directly related to other factors at other levels, which are the most basic quality defect control elements for sleeve grouting construction. Specific guidelines are recommended as follows: (i) establish a strict raw material quality inspection system and improve the inspection process, such as image and video data acquisition. (ii) It is necessary to improve the mobilization process of prefabricated components, arrange the component storage yard in an organized manner, and take 
protective measures for components that are stored in the open-air environment. (iii) To maintain the mental state of workers, it is necessary to formulate reasonable working hours with break time to maintain worker efficiency and wellbeing.

(3) The third-level control strategy mainly focuses on the prefabricated building component installation and grouting operation. According to the grouting process, several key quality control points need to be known: (i) check the component grouting channel and remove any debris to maintain an unobstructed slurry path; (ii) after the slurry is prepared according to the specified mix proportion, check the fluidity of the grouting material to ensure that the bubbles are completely discharged after letting it stand for the required amount of time; (iii) the sleeve and reinforcement shall be installed accurately to ensure that the verticality, anchorage length, and other parameters meet the quality requirements; (iv) check that the grouting joint is sealed tightly and meets the quality requirements of setting time required for grouting; (v) the grouting speed should be strictly controlled to avoid quality defects such as hollowing (too slow) and blocking (too fast); (vi) the outlet should be sealed firmly with wooden or rubber plugs immediately, thereby avoiding the grouting noncompactness due to slurry leakage caused by plug malfunction.

\section{Conclusion}

In recent years, the Chinese government has promoted the transformation of the construction industry to uphold a high level of quality and low level of pollution. From this foundation, prefabricated building construction and its key node connection technology have been developed. However, in practical application, the problem of sleeve grouting defects has been difficult to resolve. The quality influencing factors are complex and its action mechanism is unclear and lacks systematic identification and strategy analysis. This study identified 18 key factors of sleeve grouting noncompactness by applying a combined approach of literature review, brainstorming, and expert interview. The ISM method was then applied to structure the factors into a hierarchy of six distinct levels, and the MICMAC tool was used to classify the factor attributes, including seven variables, four autonomous variables, and seven independent variables. The results reveal the internal relationship among the factors affecting the quality of sleeve grouting, based on which a three-level strategy is recommended to facilitate the sleeve grouting process in China's prefabricated building construction industry.

Some unique research highlights of this study include the following: (i) the single-factor sleeve grouting quality analysis is extended to the factor system and the internal relationship analysis of its factors; (ii) from the perspective of assigning importance to human and external environments, the factors related to the mental state of workers, working environment, and weather conditions are included in the factor system, and the corresponding strategic suggestions are made; (iii) each factor is analyzed from the aspects of structure position, driving force, and dependent force. Besides, the research method and results of this study are not limited to China's construction industry. First, sleeve connection technology is widely used in other countries, such as Singapore and Japan, and grouting quality problems are common. Second, although different problems may be caused by different construction techniques and management methods in different regions, the methods and perspectives of this study could provide a useful reference for other economies to investigate the sleeve grouting quality barriers. Finally, more information technology needs to be applied and updated in the area of quality supervision to improve the quality of the construction process and construction products.

This study has limitations that should not be overlooked. First, the identified key factors are concerned with on-site construction, and the impact of other stages is not taken into account, such as the design defects. Second, the field investigation mainly focuses on the demonstration project, thereby lacking the application analysis of sleeve grouting technology in conventional prefabricated building projects. Third, due to the limitation of the ISM method, there is a lack of comprehensive analysis of all sleeve grouting quality factors.

\section{Data Availability}

All data generated or analyzed during the study are included within the paper, and the basic data information is mainly listed in Tables 3-5.

\section{Conflicts of Interest}

The authors declare that they have no conflicts of interest.

\section{Acknowledgments}

This research was supported by the National Key R\&D Program of China (grant nos. 2016YFC0701810 and 2016YFC0701800). The authors would like to especially thank the experts, scholars, and engineering construction personnel who participated in the research.

\section{References}

[1] F. Yao, G. Liu, Y. Ji et al., "Evaluating the environmental impact of construction within the industrialized building process: a monetization and building information modelling approach," International Journal of Environmental Research and Public Health, vol. 17, no. 22, 2020.

[2] Y. Ji, S. Chang, Y. Qi, Y. Li, H. X. Li, and K. Qi, “A BIM-based study on the comprehensive benefit analysis for prefabricated building projects in China," Advances in Civil Engineering, vol. 2019, pp. 1-13, 2019.

[3] R. Zhang, A. S. J. Zhou, S. Tahmasebi, and J. Whyte, "Longstanding themes and new developments in offsite construction: the case of UK housing," Proceedings of the Institution of Civil Engineers - Civil Engineering, vol. 172, no. 6, pp. 29-35, 2019. 
[4] F. Yao, Y. Ji, and H. X. Li, "Evaluation of informatization performance of construction industrialization EPC enterprises in China," Advances in Civil Engineering, vol. 2020, pp. 1-18, 2020.

[5] W. Zhu, L. Shao, Y. Wang, and W. Fu, "Study on semigrouting coupler connecting technology for steel reinforcement," Architecture Technology, vol. 46, no. 10, pp. 937-940, 2015.

[6] W. Zhu, Q. Ma, C. Ma, and J. LI, "Introduction of grouting sleeve joint technology for prefabrication and assembly of building structures," Architectural Science, vol. 30, no. 1, pp. 109-130, 2014.

[7] W. Xu, P. Zhang, F. Wei, and X. Hu, "Grout sleeve splicing application in precast concrete structures," Construction Thecnology, vol. 43, no. S2, pp. 567-569, 2014.

[8] B. Mou, X. Li, Y. Bai, and L. Wang, "Shear behavior of panel zones in steel beam-to-column connections with unequal depth of outer annular stiffener," Journal of Structural Engineering, vol. 145, no. 2, 2019.

[9] Y. Ji, K. Li, G. Liu, A. Shrestha, and J. Jing, "Comparing greenhouse gas emissions of precast in-situ and conventional construction methods," Journal of Cleaner Production, vol. 173, pp. 124-134, 2018.

[10] C. Zhang and H. Wang, "Swing vibration control of suspended structure using active rotary inertia driver system: parametric analysis and experimental verification," Applied Sciences, vol. 9, no. 15, 2019.

[11] C. Zhang and H. Wang, "Swing vibration control of suspended structures using the Active Rotary Inertia Driver system: theoretical modeling and experimental verification," Structural Control and Health Monitoring, vol. 27, no. 6, 2020.

[12] L. Zhu, L. Kong, and C. Zhang, "Numerical study on hysteretic behaviour of horizontal-connection and energy-dissipation structures developed for prefabricated shear walls," Applied Sciences, vol. 10, no. 4, 2020.

[13] C. Zhao, Z. Cao, J. Chen, F. XU, S. Long, and C. Yang, “The research status on the seismic behavior of prefabricated reinforced concrete column with longitudinal rebargrouted connection," Industrial Construction, vol. 49, no. 5, pp. 126132, 2019.

[14] Y. Bai, S. Wang, B. Mou, Y. Wang, and K. A. Skalomenos, "Bidirectional seismic behavior of steel beam-column connections with outer annular stiffener," Engineering Structures, vol. 227, 2021.

[15] C. Li, L. Sun, Z. Xu, X. Wu, T. Liang, and W. Shi, "Experimental investigation and error analysis of high precision FBG displacement sensor for structural health monitoring," International Journal of Structural Stability and Dynamics, vol. 20, no. 6, 2020.

[16] C. Zhang, G. Gholipour, and A. A. Mousavi, "Blast loads induced responses of RC structural members: state-of-the-art review," Composites Part B: Engineering, vol. 195, 2020.

[17] C. Zhang, G. Gholipour, and A. A. Mousavi, "State-of-the-art review on responses of RC structures subjected to lateral impact loads," Archives of Computational Methods in Engineering, vol. 15, 2020.

[18] Z. Alam, C. Zhang, and B. Samali, "The role of viscoelastic damping on retrofitting seismic performance of asymmetric reinforced concrete structures," Earthquake Engineering and Engineering Vibration, vol. 19, no. 1, pp. 223-237, 2020.

[19] H. Huang, M. Huang, W. Zhang, S. Pospisil, and T. Wu, "Experimental investigation on rehabilitation of corroded RC columns with BSP and HPFL under combined loadings," Journal of Structural Engineering, vol. 146, no. 8, 2020.
[20] H. Huang, M. Huang, W. Zhang, and S. Yang, "Experimental study of predamaged columns strengthened by HPFL and BSP under combined load cases," Structure and Infrastructure Engineering, vol. 4, pp. 1-18, 2020.

[21] J. Liu, Y. Yi, and X. Wang, "Exploring factors influencing construction waste reduction: a structural equation modeling approach," Journal of Cleaner Production, vol. 276, 2020.

[22] J. Liu, Y. Liu, and X. Wang, "An environmental assessment model of construction and demolition waste based on system dynamics: a case study in Guangzhou," Environmental Science and Pollution Research, vol. 27, no. 30, pp. 37237-37259, 2020.

[23] M. Abedini and C. Zhang, "Performance assessment of concrete and steel material models in LS-DYNA for enhanced numerical simulation, a state of the art review," Archives of Computational Methods in Engineering, vol. 21, 2020.

[24] F. Yao, Y. Ji, W. Tong, H. X. Li, and G. Liu, "Sensing technology based quality control and warning systems for sleeve grouting of prefabricated buildings," Automation in Construction, vol. 123, 2021.

[25] C. Zhang, M. Abedini, and J. Mehrmashhadi, "Development of pressure-impulse models and residual capacity assessment of RC columns using high fidelity Arbitrary LagrangianEulerian simulation," Engineering Structures, vol. 224, 2020.

[26] Q. Zheng, N. Wang, L. Tao, and X. Tian, "Experimental study on effects of grout defects on the connection behaviors of grout sleeve splicing for reinforcing bars," Building Science, vol. 33, no. 5, pp. 61-68, 2018.

[27] Z. Kuang, G. Zheng, and X. Jiao, "Experimental study on effect of mechanical behavior of grout sleeve splicing reinforced bars due to lack of grout," Journal of TongJi University (Natural Science), vol. 47, no. 7, pp. 934-945, 2019.

[28] X. Li, R. Gao, Q. Xu, Z. Wang, and F. Zhang, "Experimental study on influence of grouting defect on joint strength of grout sleeve splicing of rebars," Building Structure, vol. 48, no. 7, pp. 52-56, 2018.

[29] H. Huang, M. Guo, W. Zhang, J. Zeng, K. Yang, and H. Bai, "Numerical investigation on the bearing capacity of RC columns strengthened by HPFL-BSP under combined loadings," Journal of Building Engineering, vol. 39, 2021.

[30] W. Zhang, Z. Tang, Y. Yang, and J. Wei, "Assessment of FRP-concrete interfacial debonding with coupled mixedmode cohesive zone model," Journal of Composites for Construction, vol. 25, no. 2, 2021.

[31] Y. Ju, T. Shen, and D. Wang, "Bonding behavior between reactive powder concrete and normal strength concrete," Construction and Building Materials, vol. 242, 2020.

[32] Y. Xiong, J. Li, B. sun, and S. Mao, "Strength and influencing factors of grouting material for assembled building sleeve," Journal of Building Materials, vol. 22, no. 2, pp. 272-277, 2019.

[33] Q. Jin, B. Sun, D. Cui, S. Mao, and J. Zhang, "Experimental study on mechanical properties of reinforced sleeve grouting joint after high temperature," Building Structure, vol. 48, no. 23, pp. 38-42, 2018.

[34] D. Li and X. Li, "Research on the driving factors of prefabricated buildings based on interpretative structural Model (ISM)," Construction Economy, vol. 40, no. 1, pp. 87-91, 2019.

[35] J. Zhou and P. He, "Analysis the influence factors of prefabricated building cost based on interpretative structural model (ISM)," Journal of Engineering Management, vol. 33, no. 1, pp. 39-44, 2019.

[36] T. Tan, K. Chen, F. Xue, and W. Lu, "Barriers to Building Information Modeling (BIM) implementation in China's prefabricated construction: an interpretive structural 
modeling (ISM) approach," Journal of Cleaner Production, vol. 219, pp. 949-959, 2019.

[37] G. Liu, Z. Wen, X. He, and J. Shen, "Factors affecting the quality of prefabricated concrete building based on ISMMICMAC," Journal of Civil Engineering and Management, vol. 36, no. 5, pp. 33-39, 2019.

[38] Y. Zhang, "Quality control of reinforcement sleeve grouting construction in fabricated integral concrete structure project," Structure Construction, vol. 41, no. 2, pp. 229-249, 2019.

[39] L. Qiu and Y. Qian, "Study and countermeasures of reinforcement sleeve grouting joint construction," Sichuan Building Materials, vol. 45, no. 11, pp. 83-94, 2019.

[40] H. Li, P. Zhang, and Y. Zhang, "Review on the wet connection of prefabricated building joints," Technology Wind, vol. 6, pp. 97-98, 2019.

[41] Z. Li and L. Hu, "Discussion on quality process control of grouting coupler," Use \& Management, vol. 40, no. 7, pp. 65-67, 2019.

[42] C. Wang, W. Cai, J. Zhuo, J. Zhang, B. Liao, and Z. Li, "Review on the development of prefabricated buildings and connection joints at home and abroad," Urban Housing, vol. 26, no. 5, pp. 132-135, 2019.

[43] H. Zheng, Y. Ming, F. Tian, and M. Wang, "Study on preparation and pouring technique test of fiber reinforced grouting material for connection in steel-concrete composite beam," Construction Technology, vol. 48, no. 5, pp. 58-114, 2019.

[44] S. Huang, W. Zhu, and Y. Wang, "Preparation and properties of high performance cementitious grout for prefabricated concrete structure," New Building Materials, vol. 46, no. 6, pp. 10-13, 2019.

[45] M. Huang, "A brief discussion on the material requirements of reinforced grouting sleeve connection in prefabricated building," Sichuan Cement, vol. 8, p. 297, 2019.

[46] P. Gao and S. Zhang, "Research on grouting material for assembled construction sleeve," Jiangsu Building Materials, vol. 4, pp. 28-31, 2019.

[47] J. Chen, Q. Jin, H. Zhao, and C. Shi, "Experimental study on properties of sleeve grouting materials under high temperature," Jiangxi Building Materials, vol. 9, pp. 20-22, 2019.

[48] Z. Ma, P. Song, and X. Hang, "Properties effect of admixture on negat ive temperature sleeve grout ing material," Concrete, vol. 5, pp. 142-150, 2019.

[49] S. Yang, X. Li, and Z. Wang, "Research and application of steel sleeve connection grouting material in winter construction of assembled buildings," Construction Thecnology, vol. 48, no. 3, pp. 28-31, 2019.

[50] C. Huang, "Research on construction technology of sleeve grouting in prefabricated high-rise buildings," Low Carbon Orld, vol. 9, no. 1, pp. 165-166, 2019.

[51] Q. Yan, "Application and construction of grouting sleeve in fabricated structure," Fujian Building Materials, vol. 1, no. 12, pp. 46-48, 2018.

[52] Z. Alam, L. Sun, C. Zhang, Z. Su, and B. Samali, "Experimental and numerical investigation on the complex behaviour of the localised seismic response in a multi-storey plan-asymmetric structure," Structure and Infrastructure Engineering, vol. 17, no. 1, pp. 86-102, 2020.

[53] Z. Alam, C. Zhang, and B. Samali, "Influence of seismic incident angle on response uncertainty and structural performance of tall asymmetric structure," The Structural Design of Tall and Special Buildings, vol. 29, no. 12, 2020.
[54] J. Xue and P. Tan, "Research on application of BIM-3D printing technology in construction of special-shaped concrete members," Concrete, vol. 6, pp. 166-174, 2020.

[55] R. Gao, X. Li, F. Zhang, Q. Xu, Z. Wang, and H. Liu, "Experiment on detection of coupler grouting compactness based on industrial," X-CT, vol. 39, no. 4, pp. 6-11, 2017.

[56] Z. Li and H. Chen, "Application of grouting sleeve in precast concrete components," Construction Technology, vol. 40, no. 10, pp. 54-56, 2019. 